\title{
Modified allele-specific PCR improves HER2 Ile655Val detection by reducing genotyping errors
}

\author{
Bugi Ratno Budiarto ${ }^{1 *}$, Azamris $^{2^{*}}$ and Desriani ${ }^{*}$
}

\begin{abstract}
Background: A reliable method to detect gene polymorphisms must be established to eliminate genotyping errors due to false PCR amplification. In the previous study, we have developed AS-PCR (Allele Specific-Polymerase Chain Reaction) to detect HER2 lle655Val gene polymorphism with good specificity and sensitivity, yet it produces some errors. This study is aimed to eliminate the source of genotyping errors mainly by betaine treatment and PCR program modification.

Methods: Genotyping errors produced by AS-PCR was qualitatively and quantitatively evaluated using two genomic DNA that each contained AA genotype and GG genotype of HER2 Gene. Betaine treatment or PCR program modification was tested to eliminate the occurrence of genotyping errors during AS-PCR amplification.

Results: The types of genotyping errors exhibited by HER2 lle655Val AS-PCR are diverse, ranging from LDO (Locus Drop Out), preferential amplification to ADO (Allele Drop Out). The rate of genotyping errors was from $10 \%$ to $50 \%$ depending on the amount and ratio of DNA template and the annealing temperature of PCR. In the mixed DNA template model, the betaine treatment has shown to reduce ADO only in preferentially amplified GG genotype amplicon. Alternatively, reducing the template of the heterozygous DNA by half ( $-0.5 \mathrm{ng}$ of DNA template) for such case has effectively recovered the AS-PCR from ADO. Furthermore, increasing the denaturation temperature to $96{ }^{\circ} \mathrm{C}$ with an annealing time of $40 \mathrm{~s}$ at the first 10 cycles of AS-PCR has succeeded in eliminating severe preferential amplification of AA genotype amplicon by preventing the DNA template with GG genotype from forming into a G-quadruplex structure. The guideline offered in this study has been successfully applied for clinical samples of breast cancer that show preferential amplification.
\end{abstract}

Conclusion: Betaine and the modifying AS-PCR program can reduce significantly genotyping errors making AS-PCR for HER2 lle655Val detection more reliable to be used as a molecular tool for genotyping purpose.

Keywords: Genotyping errors, Allele-specific PCR, Polymorphism, Codon HER2 lle655Val

\section{Background}

Human epidermal growth factor receptor-2 (HER2/erbB2) gene has been linked to cancer development [1]. The product of this gene, HER2 membrane receptor in normal cells condition has a function to coordinate cells growth and differentiation tightly [2]. Although no specific ligand has been identified for HER2 receptor so far, the biological

\footnotetext{
* Correspondence: budiarto_bugie@yahoo.com;

drazamrisspbonk@yahoo.com; gerodes@yahoo.com

${ }^{1}$ Research Center for Biotechnology, Indonesian Institute of Sciences (LIPI), Jalan Raya Bogor Km. 46, Cibinong 16911, Indonesia

${ }^{2}$ Faculty of Medicine, Andalas University, Jalan Perintis Kemerdekaan No.94, Padang, Indonesia
}

(c) The Author(s). 2017 Open Access This article is distributed under the terms of the Creative Commons Attribution 4.0 International License (http://creativecommons.org/licenses/by/4.0/), which permits unrestricted use, distribution, and reproduction in any medium, provided you give appropriate credit to the original author(s) and the source, provide a link to the Creative Commons license, and indicate if changes were made. The Creative Commons Public Domain Dedication waiver (http://creativecommons.org/publicdomain/zero/1.0/) applies to the data made available in this article, unless otherwise stated. impact of this protein on the cells signaling transduction tion with other members of erbB familly such as HER1, HER3 or HER4 protein [3]. Therefore, it is not surprising that overexpression of HER2 gene product due to mutation tends to increase the rate of proliferation of breast cells uncontrollably, leading to breast carcinogenesis $[4,5]$. This aberrant of HER2 oncogene product is counted for 20 to $30 \%$ of breast cancer incidence [6]. Despite the fact that the status of HER2 gene copy number has been well 
recognized associating with breast cancer development, recent epidemiological data has also suggested that HER2 genetic polymorphism at codon 655 (HGVS: NC_000017.10:g.37879588A > G, dbSNP: rs1136201) may contribute to this malignancy. Polymorphism at codon 655 of HER2 protein as susceptibility biomarker for breast cancer was first evaluated in a Chinese population [7]. They concluded that breast cancer risk impacted more significantly at young women (under 42 years old) whose HER2 codon 655 contained valine variant. Moreover, meta-analysis through 27 published articles concluded that HER2 Ile655Val polymorphism was associated with an increased breast cancer risk especially among the African and Asian population when adjusted for ethnicity [8]. On the other hand, the decrease in risk of this SNP to breast cancer also have been reported in Caucasian women or European women descent $[9,10]$. The contrast finding to each other may arise from laboratory artifacts, bad experiment procedure, and publication bias [11]. Nevertheless, recent clinical data highlights the usefulness of HER2 Ile655Val polymorphism as a biomarker for cardiotoxicity in trastuzumab-treated HER2 positive breast cancer patients [12].

In attempt to develop a molecular method to detect HER2 Ile655Val polymorphism in breast cancer, our previous work has established Allele-Specific PCR with lowcost, rapid, and high accuracy to distinguish among HER2 variants [13]. However, genotyping errors such as LDO and ADO still interferes the reliability of this method. Therefore, the experimental study which is aimed to eliminate such errors must first be established before the method can really be applied for diagnosis purposes. In fact, breast cancer patients with HER2 positive are strongly recommended to test HER2 genotype status prior to trastuzumab therapy to avoid cardiotoxicity induced by this antibody [14].

In general, cumulative error rate due to genotyping errors in genetics study is around of $0.22 \%$ [15]. Genotyping errors arising from the use of PCR method are the common problem faced mainly in forensics DNA analysis and PGD (Preimplantation Genetic Diagnostics) in which degraded biological materials and single cell are used for genetics analysis. Error rate approximately of $57.5 \%$ due to ADO and false positive, depending on the quality of samples and PCR technique applied, was produced in forensics DNA analysis [16]. ADO is the prominent cause of misdiagnosis in PGD and SNP-based population genetics studies. It also reduces the success of IVF (in vitro fertilization) [17]. Although a number of overall error rate is small, yet this number would bring prominent impact on patients management persepctive. Therefore, methods with accuracy are near to $100 \%$ must be selected for clinical testing pusrposes to prevent misdiagnosis $[18,19]$.
Allele Drop Out (ADO) is preferential amplification of one of the alleles for heterozygote DNA template by DNA polymerase because of suboptimal PCR condition, or stochastic fluctuation effect [20]. Imbalance in proportion of heterozygote allele after PCR prosess is often observed in many gene polymorphisms studies [20-22]. Under certain circumstances, amplicon of one allele of the heterozygote variant may exhibit very faint PCR band or even no PCR product on DNA agarose. This situation will increase the probability for false detection due to allellic data missclasification during genotyping testing on the sample. The importance of this issue has risen the awareness regarding the good quality control of procedures that must be applied in every step of detections strictly. In some laboratories, the sterile approach has been implemented to prevent any contaminations (DNA or DNAse contaminant) from the environment that could be accidentally co-added into PCR solution [23]. Those of two contaminants are the major causes for generating PCR false positive/negative results. Moreover, efforts have been established to reduce genotyping errors such as (1) selections of appropriated DNA extraction methods through buffer optimization in way to obtain two alleles with similar proportion [21] (2) designing primers uses suitable bioinformatics approach with paying attention to the existences of additional SNPs on primer DNA sequences beside targeted SNPs [22, 24], (3) doing PCR amplification with replication [19], (4) optimizing PCR conditions [25], and (5) adding chemical enhancers into PCR reaction [26].

There is a contrast result of allele frequency of HER2 Ile655Val that comes from Asian population versus African population in many published studies regarding its role as a risk factor for breast cancer [7, 27-29]. It has been known that the latter population indeed deviates from HardyWienberg Equilibrium, Indicating there could be a result of some technical errors in methodology applied, although some believe that this discrepancy is possibly because of difference in ethnicity [30]. However, a study has confirmed that methodological errors approximately contributes to incorrect detection as much as 14 up to 58\% [31]. This highlighted that the application of molecular tools with the low errors rate for this purposes become a basic prerequisite. Studies of genotyping errors related to the AS-PCR application for HER2 Ile655Val detection no detailed reports have been published until recently. Therefore, the purposes of this study are (1) to evaluate the possibility of any genotyping errors in AS-PCR for HER2 Ile655Val polymorphism detection and (2) to establish an AS-PCR formulation in which the genotyping errors could be eliminated.

\section{Methods}

Patient samples collection and DNA extraction

HER2 Ile655Val-containing genomic DNA was obtained from frozen sections of breast tissue samples collected 
from M. Djamil Hospital Padang, West Sumatera Province. Genomic DNA was then extracted followed manual tissue DNA extraction protocol (Pure Link Genomic DNA Mini Kit; Invitrogen, Thermo Fisher Scientific Inc., USA). The types of HER2 Ile655Val alleles of this DNA have been confirmed using Sanger DNA sequencing and AS-PCR as described in the previous study [13]. These genomic DNA were used in AS-PCR for genotyping errors study and its optimization. Another clinical samples were collected and their DNA were extracted using the same protocol, then the types of SNP HER2 Ile655Val were established using AS-PCR. We collected five breast cancer samples that showed HER2 Ile655Val heterozygote. We coded these samples as number 1 to 5 for simplicity. All subjects enrolled in this experiment were approved by the local ethics committee, issued by the Ministry of Health, the Republic of Indonesia.

\section{PCR reagents}

PCR Supermix reagent for AS-PCR experiment was purchased from Invitrogen, Thermo Fisher Scientific.Inc., USA. All primers as listed in Table 1 were purchased from Integrated DNA Technologies.Inc., USA. Betaine was purchased from Sigma-Aldrich, USA. Betaine was stored as $10 \mathrm{M}$ stock in $\mathrm{dH}_{2} \mathrm{O}$ at $-20{ }^{\circ} \mathrm{C}$.

\section{Allele-specific PCR experiment for gentyping errors evaluation}

Qualitative evaluation of AS-PCR for the occurance of genotyping errors was done using mixed DNA template model with varying the amount of DNA template with AA genotype from 1, 0.25, 0.06 and $0.01 \mathrm{ng}$ while kept DNA template with GG genotype at $1 \mathrm{ng}$ vice versa. Each of $12.5 \mathrm{~mL}$ reaction mixture contained $11.25 \mathrm{~mL}$ of PCR Super Mix buffer, primers, and templates. The PCR amplification profile was as follows: initial denaturation at $95{ }^{\circ} \mathrm{C}$ for $5 \mathrm{~min}$, followed by 35 cycles of denaturation at $95{ }^{\circ} \mathrm{C}$ for $20 \mathrm{~s}$, annealing temperature at $54.3{ }^{\circ} \mathrm{C}$ for $20 \mathrm{~s}$, and extension at $72{ }^{\circ} \mathrm{C}$ for $30 \mathrm{~s}$. All PCR tubes, distilled water, pipette tips, and pipettes were pretreated by exposing on UV-light for 15-20 min prior to use.

Quantitative evaluation of AS-PCR to evaluate the rate of genotyping errors due to ADO and LDO was done using multiple tube assay as suggested by Taberlet et al. [18]. This method offers quantification of genotyping errors not only caused by stochastic effect due to low DNA template but also quantifying errors due to PCRrelated conditions when standard DNA template was used during amplification. The genotyping errors were tested for each variant of HER2 Ile655Val alleles and errors rate as a percentage was calculated based on a total number of amplicon with correct genotype divided with amplicon with incorrect genotype or noamplification. Preferential amplification was considered as correct genotype in a case of heterozygous DNA. AS-PCR condition followed the composition as mentioned above. For evaluating the effect of DNA template amount on genotyping errors, the annealing temperature was set at $54.3{ }^{\circ} \mathrm{C}$. While for evaluating the effect of annealing temperature on genotyping errors for each homozygous DNA, the amount of DNA template was used as much as $0.4 \mathrm{ng}$ and for heterozygous DNA was mixed $1 \mathrm{ng}$ each.

\section{Allele-specific PCR experiment for genotyping errors elimination}

Pre-PCR treatment by betaine and modifying AS-PCR program on mixed DNA template sample model and clinical samples that showed preferential amplification was done. In mixed DNA template model, $0.125 \mathrm{M}$ and $0.25 \mathrm{M}$ betaine were added into PCR solutions that contain both of SNP-known DNA templates with differing the amount of DNA template ratio. For this purpose, AS-PCR components and AS-PCR program followed the condition as mentioned in the first AS-PCR experiment. The occurrence of preferential amplifiication on betained-treated AS-PCR experiment, then was further modified by changing the AS-PCR condition as follow: initial denaturation at $96{ }^{\circ} \mathrm{C}$ for $5 \mathrm{~min}$, followed by first 10 cycles of denaturation at $96{ }^{\circ} \mathrm{C}$ for $20 \mathrm{~s}$ or $40 \mathrm{~s}$, annealing temperature at $54.3{ }^{\circ} \mathrm{C}$ for $40 \mathrm{~s}$, and extension at $72{ }^{\circ} \mathrm{C}$ for $30 \mathrm{~s}$. While for the next 20 cycles of AS-PCR, the same program as at the first AS-PCR experiment was used. For clinical samples, $0.5 \mathrm{ng}$ of DNA template was used and the same protocol was applied to eliminate genotyping errors. Analysis of the AS-PCR products was done by electrophoresis in $3 \%$ agarose gels containing $1 \times$ TE buffer. Staining was with ethidium bromide. Pictures of the stained gels were taken with Canon IXUS camera under UV-light exposure.

Table 1 List of primers used in this study [13]

\begin{tabular}{|c|c|c|c|c|}
\hline Primer & nucleotide sequence & Tm primer $\left({ }^{\circ} \mathrm{C}\right)$ & Amplicon Size (bp) & $\begin{array}{l}\text { Primer conc. }(\mu \mathrm{M}) \\
\text { in AS-PCR }\end{array}$ \\
\hline Her2-AA-Forward & 5'-CCAGCCCTCTGACGTCCAGCA-3' & 63.9 & 142 & 0.6 \\
\hline Her2-GG-Forward & 5'GCGGGCAGGGCGGCGGGGGCGGGGCCCCAGCCCTCTGACGTCCACCG-3' & 83 & 168 & 0.06 \\
\hline Her2-Reverse & 5'-TCCGTTTCCTGCAGCAGTCTCC-3' & 61.5 & & 0.15 \\
\hline
\end{tabular}




\section{Bioinformatics analysis of AS-PCR amplicon}

Bioinformatics analysis of G-quadruplex sequences in HER2 Ile655Val amplicon with GG genotype used QGRS Mapper (http://bioinformatics.ramapo.edu/QGRS/index.php) [32] with the optional setting: maximum lenght of the sequence was 30 , minimal G-group was 2, and loop size 0 to 36 .

\section{Results}

The AS-PCR experiment for AG genotype using mixed DNA templates with known polymorphisms that have differing ratio of each genotype was first established to evaluate types of the genotyping errors. This experiment was conducted based on previous results stating that an imbalanced heterozygote DNA used as a template in PCR can induce genotyping errors [33]. The result showed that even with equal amount of mixed DNA templates added into the AS-PCR reaction can cause preferential amplification (Fig. 1a). This type of error was further dominantly induced when the amount of the DNA templates with AA genotype differ. Meanwhile, ADO was a prominent source for erroneous reading when the amount of DNA template with AA genotype was kept constant while the amount of DNA template wtih GG genotype vary (Fig. 1b). This result confirmed that AS-PCR contains some errors, potentiating the misclassification of HER2 Ile655Val polymorphism detection.

Multiple tube assay was applied to quantitatively evaluate the related-factors of the PCR conditions that contribute to genotyping errors in the AS-PCR for each type of HER2 Ile655Val genotypes. Reducing the DNA template by a factor of two tend to increase the rate of genotyping errors and approximately $40 \%$ of these errors were caused only by LDO alone either with AA genotype or GG genotype as the starting DNA template (Table 1). Combining the DNA template of both genotypes to mimic the nature of AG variant samples would produce genotype errors that depend on their DNA proportions and quantity where the error rate varies from $10 \%$ up to $50 \%$ (Table 2). ADO was mostly produced when the ratio of the added genotypes was varied, while low mixed DNA templates tend to increase the occurrence of LDO. No errors were observed when the ratio of the mixed DNA template was 0.5:0.5 $(w / w)$. Interestingly, the annealing temperature of $54.3^{\circ} \mathrm{C}$ produced the lowest genotyping error rate (10-20\%) of all types of HER2 Ile655Val polymorphism variants. This result confirmed that the amount of DNA template and its ratio and annealing temperature used in AS-PCR were potential factors that led to genotyping errors.

Adding betaine solution, reducing the amount of DNA templates and modifying the PCR condition were applied to eliminate any type of genotyping errors produced by AS-PCR. Betaine with $0.125 \mathrm{M}$ or $0.25 \mathrm{M}$ improved the PCR detection only when the DNA template with AA genotype was equal to or one-fourth of the amount of DNA template with GG genotype, while no improvement was observed when one-fourth of the DNA template with GG genotype was used as much as the DNA template with AA genotype (Fig. 2). Surprisingly, reducing the DNA template of both genotypes by half has eliminated the preferential amplification entirely (Fig. 3a). Betaine treatment which showed no AS-PCR improvement was then modified by increasing

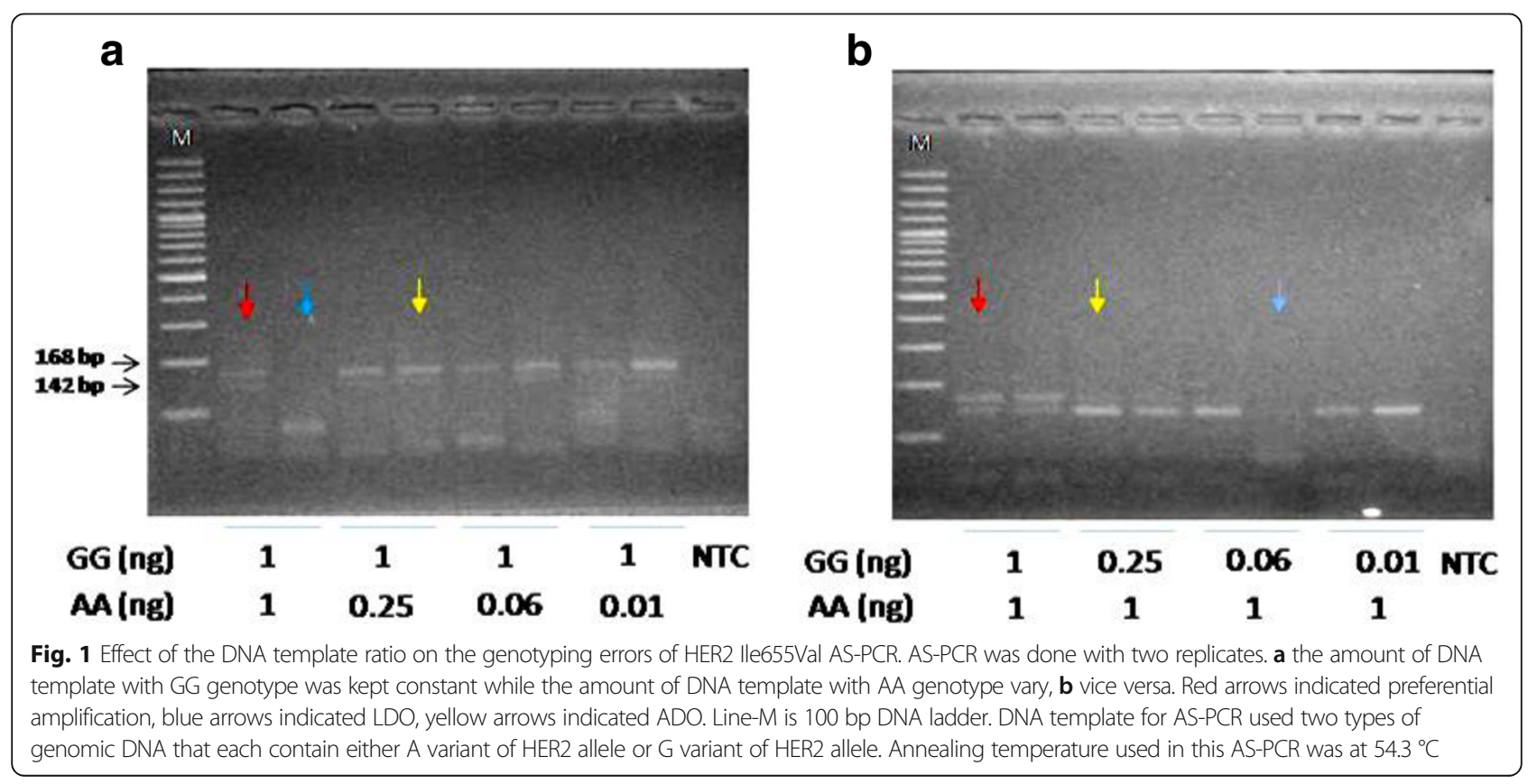


Table 2 Effects of PCR-related factors on genotyping errors of HER21655V AS-PCR for homozygous types

\begin{tabular}{|c|c|c|c|c|c|c|c|c|c|c|}
\hline \multirow{3}{*}{$\begin{array}{l}\text { Type of error } \\
\text { Experiments }\end{array}$} & \multicolumn{6}{|c|}{ DNA template concentration $(\mathrm{ng})^{\mathrm{a}}$} & \multicolumn{4}{|c|}{ Annealing temperature $\left({ }^{\circ} \mathrm{C}\right)^{\mathrm{b}}$} \\
\hline & \multicolumn{2}{|l|}{$\overline{0.4}$} & \multicolumn{2}{|l|}{0.2} & \multicolumn{2}{|l|}{0.1} & \multicolumn{2}{|l|}{51.1} & \multicolumn{2}{|l|}{57.7} \\
\hline & $1^{\text {th }}$ & $2^{\text {nd }}$ & $1^{\text {th }}$ & $2^{\text {nd }}$ & $1^{\text {th }}$ & $2^{\text {nd }}$ & $1^{\text {th }}$ & $2^{\text {nd }}$ & $1^{\text {th }}$ & $2^{\text {nc }}$ \\
\hline \multicolumn{11}{|l|}{ AA genotype } \\
\hline No PRC Product & 2 & 0 & 0 & 2 & 1 & 3 & 1 & 3 & 3 & 2 \\
\hline Correct genotype & 3 & 5 & 5 & 3 & 4 & 2 & 4 & 2 & 2 & 3 \\
\hline Total & 5 & 5 & 5 & 5 & 5 & 5 & 5 & 5 & 5 & 5 \\
\hline Mean of genotyping error rate (\%) & $20 \%$ & & $20 \%$ & & $40 \%$ & & $30 \%$ & & $50 \%$ & \\
\hline \multicolumn{11}{|l|}{ GG genotype } \\
\hline No PRC product & 1 & 1 & 1 & 2 & 2 & 2 & 2 & 1 & 0 & 2 \\
\hline Correct genotype & 4 & 4 & 4 & 3 & 3 & 3 & 3 & 4 & 5 & 3 \\
\hline total & 5 & 5 & 5 & 5 & 5 & 5 & 5 & 5 & 5 & 5 \\
\hline Mean of genotyping error rate (\%) & $20 \%$ & & $30 \%$ & & $40 \%$ & & $30 \%$ & & $20 \%$ & \\
\hline
\end{tabular}

${ }^{a}$ Allele-specific PCR was done using annealing temperatue of $54.3^{\circ} \mathrm{C}$

${ }^{\mathrm{b}}$ Allele-specific PCR was done using DNA template of $0.4 \mathrm{ng}$ for GG genotype or AA genotype

the denaturation temperature to $96{ }^{\circ} \mathrm{C}$ with an annealing time of $20 \mathrm{~s}$ to $40 \mathrm{~s}$ applied at the first 10 cycles (Fig. 3b). The modified PCR in this experiment succeeded to eliminate both ADO of GG genotype and preferential amplification of AA genotype towards GG genotype. This result showed that AS-PCR modifications can improve HER2
Ile655Val polymorphims detection by reducing genotyping errors significantly.

Bioinformatics analysis using QGRS Mapper has revealed G-quadruplex sequences in 168 bp amplicon of HER2 gene with GG genotype in both strands. A positive-strand showed two possible G4-structures with a G-score of 40

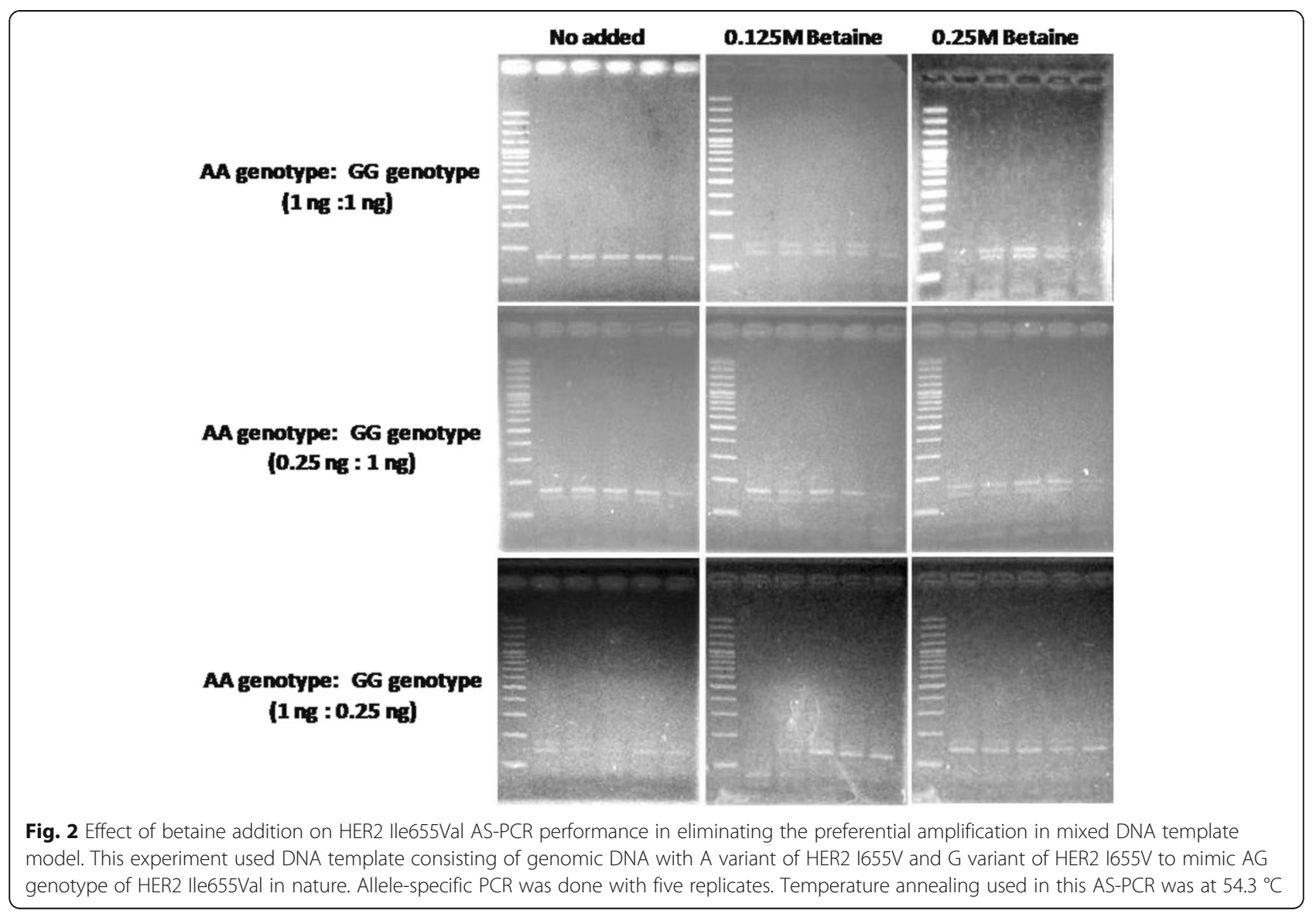


a

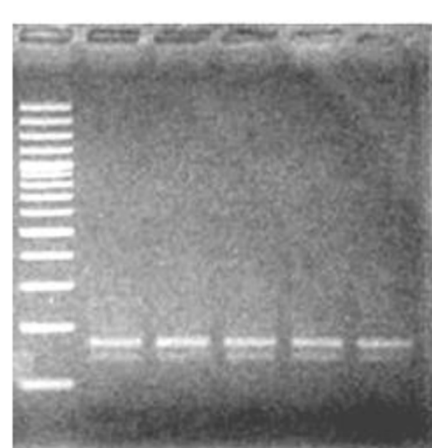

A Agenotype : GG genotype $1 \mathrm{ng}: 1 \mathrm{ng}$

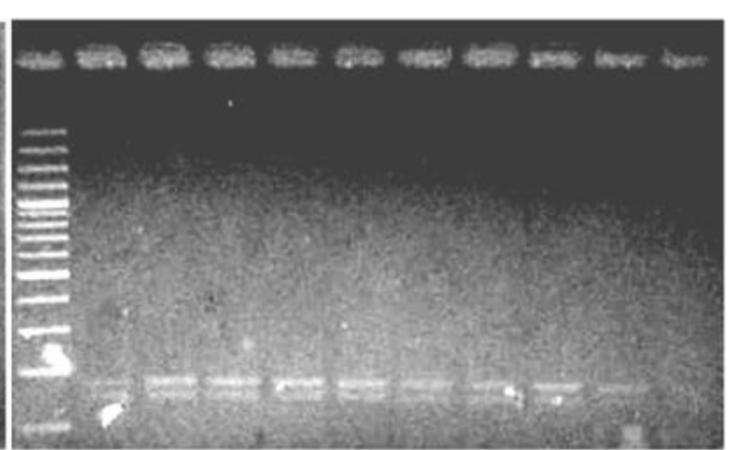

AAgenotype : GG genotype AAgenotype : GG genotype 0.5ng : $0.5 \mathrm{ng}$ $0.25 \mathrm{ng}: 0.25 \mathrm{ng}$

b

\section{Annealing time Denaturation}

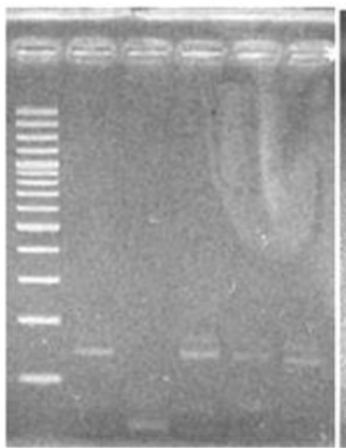

$20^{\prime \prime}$ $96^{\circ} \mathrm{C}$

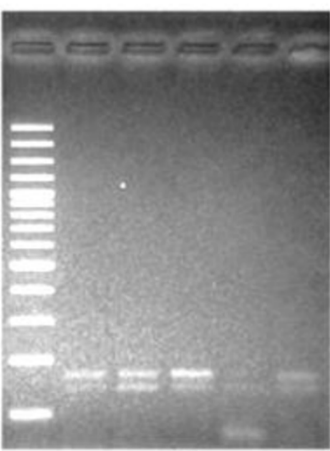

40"

Fig. 3 a effect of DNA template reducing in mixed DNA template model on preferential amplification of HER2 lle655Val AS-PCR, $\mathbf{b}$ effect of the HER2 lle655Val AS-PCR modification on eliminating the preferential amplification in mixed DNA template model (1 ng AA genotype: $0.25 \mathrm{ng}$ GG genotype). Allele-specific PCR was done with five replicates. Temperature annealing used in this AS-PCR was at $54.3^{\circ} \mathrm{C}$

and 21 at a flanking position of the targeted SNP, while the negative strand only contained one G4-structure with a G-score of 14 (Fig. 4). This result indicated that preferential amplification in the unmodified AS-PCR condition shown by heterozygous DNA samples in which the DNA template with GG genotype was less dominant can be caused by this G4-structure.
Five DNA samples extracted from breast cancer patients were evaluated for the types of genotyping errors after allele-specific amplification (Fig. 5) by following the guidelines as proposed in Fig. 6. Only two from five samples that were tested exhibited ADO as shown by the preferential amplification of AA genotype towards GG vice versa. The application of the modified AS-PCR

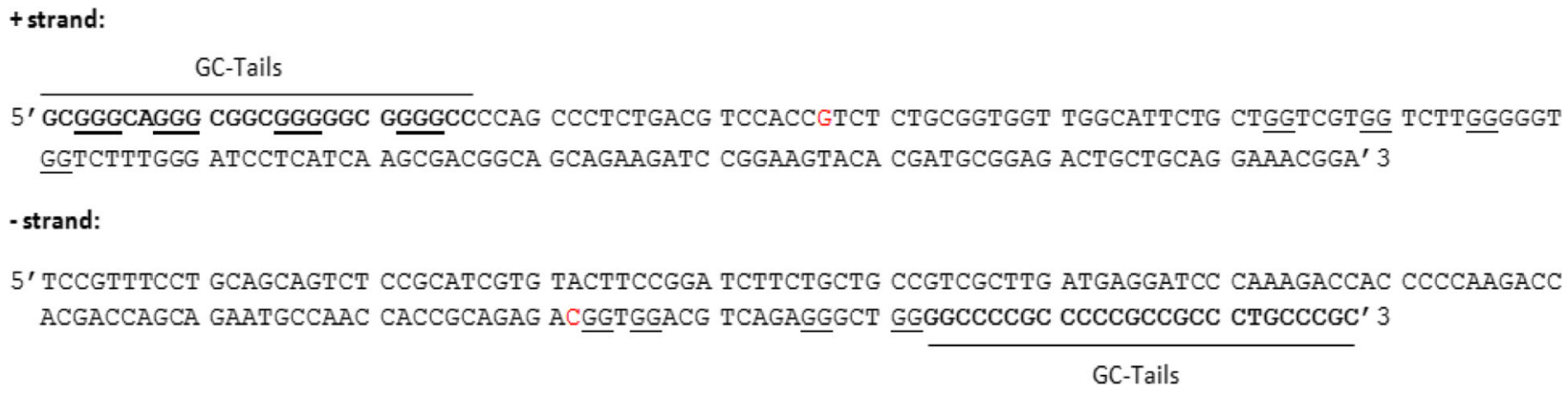

Fig. 4 The present of a G-quadruplex sequences in HER2 lle655Val amplicon with GG genotype that causes ADO. Nucleotide bases with underline represent the possible G-quadruplex structures. Nucleotide with red colour represents SNP for G variant HER2 allele 

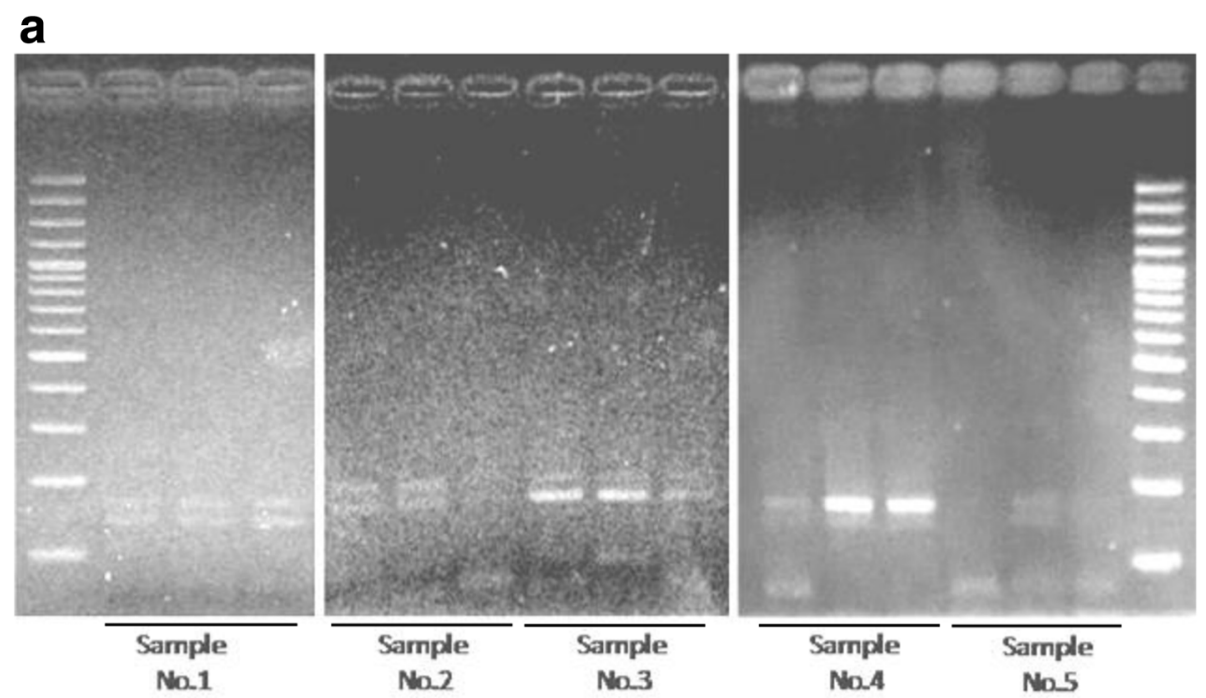

Sample

No.2

No.3

No_4 NoLS

b

c

d
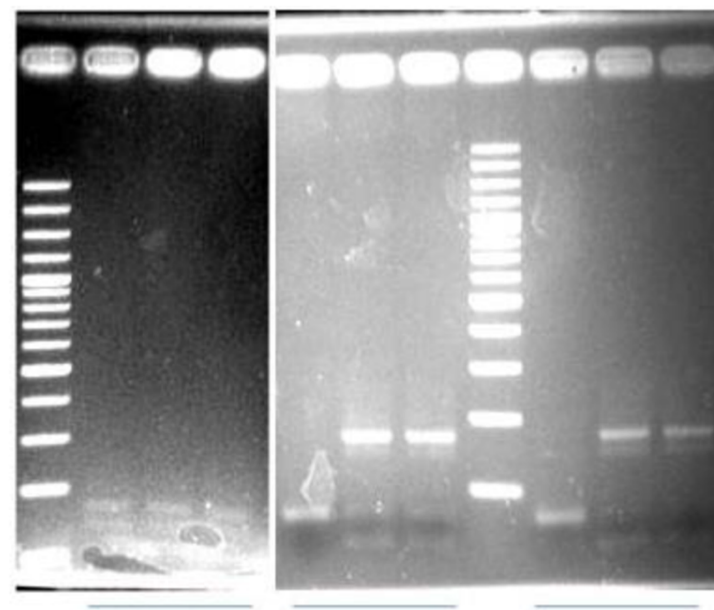

Sample

$\mathrm{No} 3$

$0.125 M$
Betaine
Sample
No-4
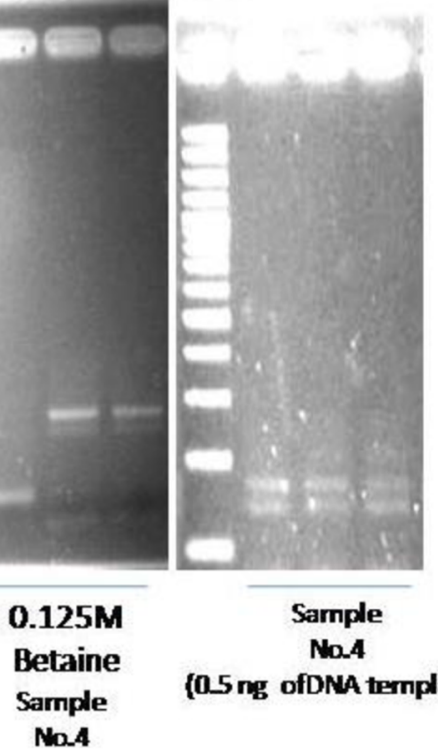

No.4

(0.5 ing ofDNA template)

Fig. 5 Effect of the modified HER2 lle655Val AS-PCR on preferential PCR amplification. a; Screening of AG genotype samples of genotyping errors-showing patients with breast cancer. $\mathbf{b}$; AS-PCR product of sample No.3 after modifying the denaturation temperature and annealing time. c; AS-PCR product of sample No. 4 after adding betaine in PCR reaction. d; AS-PCR product of sample No. 4 after adding $0.5 \mathrm{ng}$ of DNA template in PCR reaction. AS-PCR was done with three replicates of reactions using annealing temperature of $54.3{ }^{\circ} \mathrm{C}$

program on sample No. 3 could eliminate ADO significantly as no PCR product imbalance between two genotypes were observed (Fig. 5b). However, low concentration of betaine added into the AS-PCR could not eliminate ADO completely in sample No. 4. More severe ADO was observed in this sample when a high concentration of betaine was used (Fig. 5c). On the other hand, lowering the amount of DNA template in sample No.4 by half could recover AS-PCR from ADO (Fig. 5d). These results showed that both strategies have effectively reduced the cause of genotyping errors associated with AS-PCR in typing of HER2 Ile655Val alleles for clinical applications.

\section{Discussion}

A reliable estimate of the incidence of genotyping errors at the stage of the assay development is an important aspect in applying the method prior to clinical diagnostics application. In fact, the current methods applied for diagnosing polymorphisms and mutations from a high number of patient samples in clinical settings may pose a risk to produce errors [15]. To reduce the potency of such errors, we have conducted genotyping error tests on our previously developed AS-PCR before using it for genetic screening involving a large number of samples or for selecting patients benefiting from trastuzumab 


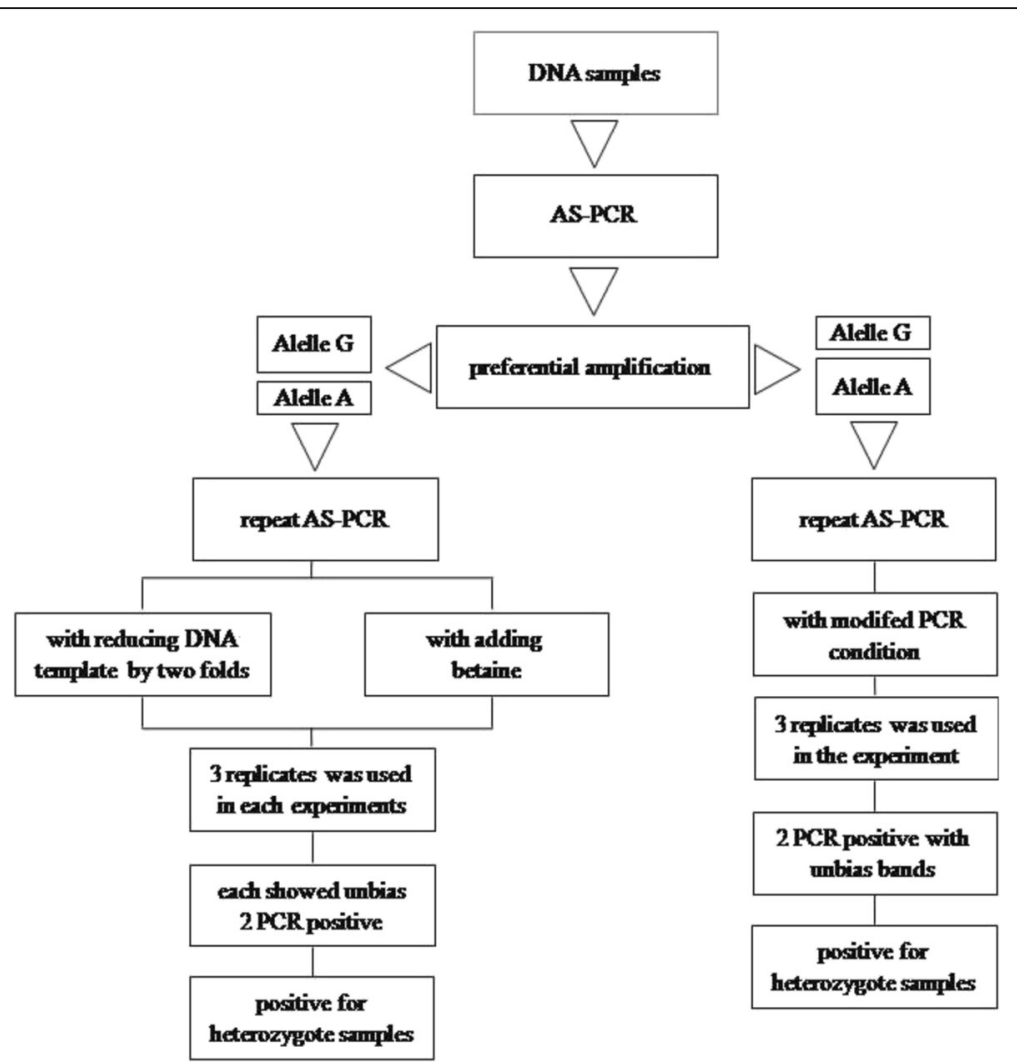

Fig. 6 Guideline for re-evaluating the heterozygote samples that show genotyping errors due to preferential amplification in HER2 Ile655Val AS-PCR

treatment. In this regard, genotyping of heterozygous samples must be carefully considered due to the presence of both allelic types in a single sample that make this type of genotype tend to produce errors when compared with the two other genotypes [34]. In fact, some DNA extraction methods have been proven to directly affect the proportion of alleles within the extracted DNA of heterozygote samples, which would contribute significantly to the occurrence of genotyping errors [33, 35]. In line with this statement, our result has confirmed that the allele-specific amplification of heterozygote DNA indeed produced errors (Fig. 1). Furthermore, we also have proven that not only heterozygous DNA but also homozygous DNA exhibited genotyping errors. Amplification using homozygote DNA templates produced similar rates and types of errors (Table 2). LDO was a prominent error when DNA was amplified at a low template. Interestingly, besides the amount of DNA template, it was also noted that the ratio of each DNA template directly affected the genotyping errors during the allele specific amplification with AG genotype (Table 3). The errors observed in our experiment were probably due to the stochastics effect during AS-PCR reaction. This event is a common phenomenon in genotyping when using DNA templates for amplification below 100 pg [36]. Stochastics effect- induced genotyping errors may occur when no DNA template was picked-up for amplification even though this allele was present in the extracted DNA solution or amplification with stutter sequence due to some kind of folding of the original strand [37, 38]. Besides low amount of DNA template, the genotyping errors can be induced by inappropriate usage of annealing temperature during the allele-specific amplification if a standard copy of DNA was used (>100 pg) as shown in our result (Tables 1, 2 and 3). Allele-specific PCR in single or in mixed-DNA templates exhibited distinct optimal amplification products that impacted directly the rate of genotyping errors. It seems that the specificity of the amplification products generated by AS-PCR strongly depends on the DNA target's GC content and on the mismatched bases within the allele-specific primers [39]. The GG genotype DNA template with an amplicon size of $168 \mathrm{bp}$ was best amplified with the lowest errors $(20 \%)$ when the annealing temperature (Ta) in AS-PCR was higher than $54.3^{\circ} \mathrm{C}$. On the contrary, the lowest error $(30 \%)$ was produced when the annealing temperature in the AS-PCR was set below $54.3^{\circ} \mathrm{C}$ for AA genotype DNA template with an amplicon size of $142 \mathrm{bp}$. The GG genotype amplicon in our experiment contained extra GC-tails as a consequence of the amplification using 
Table 3 Effects of PCR-related factors on genotyping errors of HER21655V AS-PCR for AG genotype

\begin{tabular}{|c|c|c|c|c|c|c|c|c|c|c|c|c|c|c|c|}
\hline \multirow{4}{*}{\multicolumn{2}{|c|}{$\begin{array}{l}\text { Type of error } \\
\text { Experiments }\end{array}$}} & \multicolumn{10}{|c|}{ DNA template ratio $(\mathrm{w} / \mathrm{w})^{\mathrm{a}}$} & \multicolumn{4}{|c|}{ Annealing temperature $\left({ }^{\circ} \mathrm{C}\right)^{\mathrm{b}}$} \\
\hline & & \multirow{2}{*}{\multicolumn{2}{|c|}{$\begin{array}{l}\overline{A: G} \\
1: 1\end{array}$}} & \multirow{2}{*}{\multicolumn{2}{|c|}{$\frac{A: G}{1: 0.25}$}} & \multirow{2}{*}{\multicolumn{2}{|c|}{$\frac{A: G}{0.25: 1}$}} & \multirow{2}{*}{\multicolumn{2}{|c|}{$\frac{A: G}{0.5: 0.5}$}} & \multirow{2}{*}{\multicolumn{2}{|c|}{$\frac{A: G}{0.25: 0.25}$}} & \multirow{2}{*}{\multicolumn{2}{|c|}{51.1}} & \multirow{2}{*}{\multicolumn{2}{|c|}{57.7}} \\
\hline & & & & & & & & & & & & & & & \\
\hline & & $1^{\text {th }}$ & \multirow{2}{*}{$\frac{2^{\text {nd }}}{0}$} & \multirow{2}{*}{$\begin{array}{l}1^{\text {th }} \\
0\end{array}$} & \multirow{2}{*}{$\frac{2^{\text {nd }}}{0}$} & \multirow{2}{*}{$\frac{1^{\text {th }}}{1}$} & \multirow{2}{*}{$\frac{2^{\text {nd }}}{0}$} & \multirow{2}{*}{$1^{\text {th }}$} & \multirow{2}{*}{$\frac{2^{\text {nd }}}{0}$} & \multirow{2}{*}{$\frac{1^{\text {th }}}{2}$} & \multirow{2}{*}{$\frac{2^{\text {nd }}}{1}$} & \multirow{2}{*}{$\frac{1^{\text {th }}}{1}$} & \multirow{2}{*}{$\frac{2^{\text {nd }}}{2}$} & \multirow{2}{*}{$\frac{1^{\text {th }}}{0}$} & \multirow{2}{*}{$\frac{2^{\text {nd }}}{0}$} \\
\hline LDO & No $P C R$ product & 0 & & & & & & & & & & & & & \\
\hline \multirow[t]{2}{*}{ ADO } & AA genotype only & 0 & 0 & 1 & 1 & 0 & 0 & 0 & 0 & 0 & 0 & 2 & 0 & 0 & 1 \\
\hline & GG genotype only & 0 & 1 & 0 & 0 & 1 & 2 & 0 & 0 & 0 & 0 & 0 & 0 & 0 & 0 \\
\hline \multicolumn{2}{|c|}{ Correct genotype } & 5 & 4 & 4 & 4 & 3 & 3 & 5 & 5 & 3 & 4 & 2 & 3 & 5 & 4 \\
\hline \multicolumn{2}{|l|}{ Total } & 5 & 5 & 5 & 5 & 5 & 5 & 5 & 5 & 5 & 5 & 5 & 5 & 5 & 5 \\
\hline \multicolumn{2}{|c|}{ Mean of genotyping error rate (\%) } & \multicolumn{2}{|c|}{$10 \%$} & \multicolumn{2}{|c|}{$20 \%$} & \multicolumn{2}{|c|}{$40 \%$} & \multicolumn{2}{|l|}{$0 \%$} & \multicolumn{2}{|l|}{$30 \%$} & \multicolumn{2}{|l|}{$50 \%$} & \multicolumn{2}{|c|}{$10 \%$} \\
\hline
\end{tabular}

Allele-specific PCR was done with 5 replicates in two independent experiments

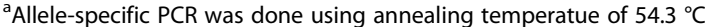

${ }^{\mathrm{b}}$ Allele-specific PCR was done using mixed DNA template of $1 \mathrm{ng}$ AA genotype and $1 \mathrm{ng}$ GG genotype

GC tails-containing primer that increases its $\mathrm{GC}$ content and therefore the extra energy by increasing Ta was accomplished to completely dissociate the DNA template during amplification. The influence of mismatched bases within the primer to the AS-PCR Stringency can be seen when the heterozygous DNA is used as a template. The level of discrimination for each genotype was maintained with a low error rate when the Ta in AS-PCR was maintained at $54.3{ }^{\circ} \mathrm{C}$ up to $57.7^{\circ} \mathrm{C}$. So that the optimization of annealing temperature ( $\mathrm{Ta}$ ) can empirically produce a good discrimination level of each HER2 Ile655Val allele which must be established in advance to reduce errors. As stated by Rychlik et al. [40] that sub or super optimal Ta value during DNA in vitro amplification may reduce or even lose the correct product.

We noticed that there was a tendency for high molecular allele weight to amplify preferentially in a heterozygous sample even when $1 \mathrm{ng}$ of each DNA template was used (Fig. 2). Our result was supported by other observations stating that the nature of polymerases to amplify DNA preferentially could be possible due to two bases (CG or GC bases) located at the 3 ' end of the primer [41]. Indeed, an allele-specific primer for detecting GG genotype in our study contained CG bases at its 3' end. Preferential amplification is a root for generating false negative PCR artifacts especially in those samples with heterozygous DNA and this event in a severe condition is predicted to lead to ADO [42]. We have also observed that preferential amplification generated by AS-PCR on heterozygous samples can result in AA genotype towards GG genotype. We have tried to eliminate preferential amplification through modification of the AS-PCR by adding betaine, reducing the amount of DNA template or by modifying the PCR condition (Figs. 2, 3 and 4). It has been known that betaine co-treatment enhances PCR stringency by eliminating the base pair composition's dependence on DNA thermal melting transition and by isostabilizing the
AT and GC pairs equally [41-45]. Interestingly, adding betaine into the AS-PCR for preferential amplificationthat showed heterozygous samples in the case of GG genotype towards AA genotype- exhibited partial effects in which only the DNA template with AA genotype was amplified significantly. No such effect was observed in the AS-PCR product of the GG genotype where low molecular weight allele amplifies preferentially. We assumed that bases at the 3'end of the allele-specific primers used in our study are a major determinant of partially enhancing the effect of betaine on AA genotype product after amplification. In fact, the allele-specific primer targeted for AA genotype was the adenine base at its 3'end which produced an AT base pair that was thermally stabilized in the presence of betaine, thus being more efficient to bind this primer to the template [46]. Betaine used in our study was 20 times up to 40 times lower than the concentration of betaine $(-5.2 \mathrm{M})$ needed to maintain the isostabilizing effect, especially on GC pairs [43]. Therefore it was not surprising that no enhanced PCR product of GG genotype was observed in the case of preferential amplification of AA genotype.

Previous studies have reported that low quality of DNA templates used in PCR as result of the suboptimal process in the DNA purification or the aged samples can produce preferential PCR amplification [21, 47]. The DNA template used in our study showed moderate to high purity of DNA as marked by a ratio of $280 / 260$ which is higher than 1.5. DNA template with AA genotype of 1.53 and the DNA template with GG genotype of 1.87. Therefore, it was apparently that preferential amplification observed in our study was not due to this factor. Soulsbury et al. [48] have identified that the quantity of DNA templates from a high-quality DNA source used in PCR affected directly the occurrence of preferential amplification and lowering the DNA template as much as 2 times from its original usage somehow succeeded 
reducing the errors. Besides betaine treatment, lowering the DNA templates in case of preferentially amplified GG genotype as suggested has succeeded in enhancing the AS-PCR product of low-molecular-weight allele to some degree that its PCR band intensity was nearly the same as the PCR band intensity of high molecular weight allele as observed in the DNA agarose (Fig. 3). We assume that this unexpected effect is due to the probability of Taq Polymerase in binding the AA genotype DNA template-targeting primer increases when the DNA template with GG genotype is diluted.

After treating the AS-PCR with betaine and since no significant improvement in reducing preferential amplification of DNA template with AA genotype was observed then we increased the annealing time of primer and the denaturating temperature during AS-PCR. Some reports have clearly confirmed that increasing both parameters during the AS-PCR for DNA with heterozygous allele can allow adequate amplification of both alleles thus avoiding ADO. Ray et al. [49] have increased the denaturation temperature from 90 to $96{ }^{\circ} \mathrm{C}$ and applied $45 \mathrm{~s}$ of annealing time of primer during the first 10 cycles and succeeded to reduce the occurrence of ADO in detecting $\Delta \mathrm{F} 508$ deletion which causes cystic fibrosis or mutation in IVS 1 region within $\beta$ globulin gene. In contrast, other study did not observe any significant effect of this modified PCR program on ADO [50]. The data from our experiment showed that setting up $96{ }^{\circ} \mathrm{C}$ for denaturation temperature with $40 \mathrm{~s}$ of primer annealing during the first 10 cycles of AS-PCR have recovered the DNA template with GG genotype from ADO. This recovering effect is probably due to a complete separation of high GC content-containing double stranded DNA template with GG genotype at a higher denaturation temperature. Hence it facilitates more allele-specific primer for GG genotype to bind into its sequence target when annealing time is prolonged. Interestingly, by using QGRS Mapper (http://bioinformatics.ramapo.edu/QGRS/index.php) [32] we have found three possible G-quadruplex structures in an amplicon of HER2 Ile655Val gene with GG genotype. Furthermore, two G4-motifs were in part of flanking sequence of the HER2 Ile655Val polymorphism, contributing significantly to cause ADO. Our finding was in agreement with Wenzel et al. [51] that stated that those types of G4-motifs could be the major cause of preferential amplification.

We have confirmed that AS-PCR contains genotyping errors and these errors were mainly caused by severe preferential amplification. We have also modeled the pattern of preferential amplification generated by the AS-PCR using allelic-typeknown DNA template mixing approach. Preferentially amplified high molecular weight of amplicon was mainly due to either the excess of DNA templates with GG genotype or even by the same ratio of mixed DNA templates. Meanwhile, preferential amplification of AA genotype was produced only when the allele was predominantly present in the heterozygous DNA template. Some modifications on the AS-PCR have been established to reduce genotyping errors mainly caused by preferential amplification on mixed-DNA template models using betaine treatment and PCR program modification. Based on theses findings, we propose the guidelines to eliminate preferential amplification which is the major cause of ADO in heterozygous samples (Fig. 6) and this strategy can be applied in clinical samples as shown by our research result (Fig. 5) in the attempt to reduce the main cause of genotyping errors.

\section{Conclusion}

Standard AS-PCR for typing HER2 Ile655Val polymorphism was hampered because of genotyping errors mainly by preferential PCR amplification. Betaine and the modifying AS-PCR program can reduce significantly genotyping errors making AS-PCR more reliable to be used as a molecular tool for genotyping purpose.

Abbreviations

ADO: Allele Drop Out; LDO: Locus Drop Out; NTC: Non-template control

\section{Acknowledgements}

We thank Rossy Angelina Latuharhary (biological student from Faculty of Matematics and Life Science, Institut Teknologi Sepuluh September) for technical support in this study during her internship program.

Consent for publications

Not applicable.

Funding

This research was financially supported by Riset Unggulan LIPI 2015 grand.

Availability of data and materials

AS-PCR experiment has been done in laboratorium of Medical Molecular Biology and Diagnostics, Research Center for Biotechnology, Indonesian Institute of Science-LIPI.

The authors declare that the data supporting the findings of this study are available within the article.

\section{Authors' contributions}

BRB carried out experimental design, conducted wet and dried lab experiments such as AS-PCR and bioinformatics analysis, analyzed data and drafted manuscript. A provided clinical samples of breast cancers. D evaluated and approved the drafted manuscript. All authors read and approved the final manuscript.

\section{Competing interest}

The authors declare that they have no competing interest.

\section{Ethics approval and consent to participate}

This study is a part of the big research entitled "Studi keragaman gen HER2/neu pada Pasien Kanker Payudara di Indonesia: Strategi Mendapatkan Obat yang Tepat Sasaran Mengatasi Permasalahan Resistensi dan Toksisitas Trastuzumab" in which all subjects enrolled in this experiment were approved by the local ethics committee, issued by the Ministry of Health, Republic of Indonesia.

\section{Publisher's Note}

Springer Nature remains neutral with regard to jurisdictional claims in published maps and institutional affiliations. 


\section{Received: 15 April 2017 Accepted: 14 August 2017}

Published online: 05 October 2017

\section{References}

1. Neve RM, Lane HA, Hynes NE. The role of overexpressed HER2 in transformation. Ann Oncol. 2001;12(Suppl 1):s9-s13.

2. Rubin I, Yarden Y. The basic biology of Her2. Ann Oncol. 2006:17:15-23.

3. Davoli A, Hocevar BA, Brown TL. Progression and treatment of HER2positive breast cancer. Cancer Chemother Pharmacol. 2010;65:611-23.

4. Bose R, Kavuri SM, Searleman AC, Shen W, Shen D, Koboldt DC, Monsey J, Goel N, Aronson AB, Li S, Ma CX, Ding L, Mardis ER, Ellis MJ. Activating HER2 mutations in HER2 gene amplification negative breast cancer. Cancer Discov. 2013:3:224-37.

5. Weigelt B, Reis-Filho JS. Activating mutations in HER2: Neu opportunities and Neu challenges. Cancer Discov. 2013:3:145-7.

6. Yarden Y. Biology of HER2 and its importance in breast cancer. Oncology. 2001;61(Suppl 2):1-13.

7. Xie D, Shu XO, Deng Z, Wen WQ, Creek KE, Dai Q, Gao YT, Jin F, Zheng W. Population-based, case-control study of HER2 genetic polymorphism and breast cancer risk. J Natl Cancer Inst. 2000:92:412-7.

8. Lu S, Wang Z, Liu H, Hao X. HER2 Ile655Val polymorphism contributes to breast cancer risk: Evidence from 27 case-control studies. Breast Cancer Res Treat. 2010;124:771-8.

9. Cox DG, Hankinson SE, Hunter DJ. The erbB2/HER2/neu receptor polymorphism lle655Val and breast cancer risk. Pharmacogenet Genomics. 2005;15:447-50.

10. Nelson S, Gould M, Hampton J, Trentham-Dietz A. A case-control study of the HER2 lle655Val polymorphism in relation to risk of invasive breast cancer. Breast Cancer Res. 2005;7:R357-64.

11. Dahabreh IJ, Murray S. Lack of replication for the association between HER2 I655V polymorphism and breast cancer risk: A systematic review and metaanalysis. Cancer Epidemiol. 2011;35:503-9.

12. Han X, Diao L, Xu Y, Xue W, Ouyang T, Li J, Wang T, Fan Z, Fan T, Lin B, Xie Y. Association between the HER2 lle655Val polymorphism and response to trastuzumab in women with operable primary breast cancer. Ann Oncol. 2014; 25:1158-64

13. Budiarto BR, Desriani. Dataset reporting detection of breast cancer-related HER21655V polymorphism using allele-specific polymerase chain reaction. Data in Brief. 2016:9:689-95.

14. Beauclair S, Formento P, Fischel JL, Lescaut W, Largillier R, Chamorey E, Hofman P, Ferrero JM, Pagès G, Milano G. Role of the HER2 [lle655Val] genetic polymorphism in tumorogenesis and in the risk of trastuzumab-related cardiotoxicity. Ann Oncol. 2007;18:1335-41.

15. Blais J, Lavoie SB, Giroux S, Bussières J, Lindsay C, Dionne J, Laroche M, Giquère $Y$, Rousseau F. Risk of misdiagnosis due to allele dropout and false-positive PCR artifacts in molecular diagnostics analysis of 30,769 genotypes. J Mol Diagnostics. 2015;17:505-14.

16. Kolodziej K, Schulz HK, Theissinger K, Ebert C, Hohmann U, Schulz R. Comparison of established methods for quantifying genotyping error rates in wildlife forensics. Conserv Genet Resour. 2013;5:287-92.

17. Harper JC. Preimplantation diagnosis of inherited disease by embryo biopsy: An update of the world figures. J Assist Reprod Genet. 1996;13:90-5.

18. Taberlet P, Griffin S, Goossens B, Questiau S, Manceau V, Escaravage N, Waits $L P$, Bouvet J. Reliable genotyping of samples with very low DNA quantities using PCR. Nucleic Acids Res. 1996;24:3189-94.

19. Miller CR, Joyce P, Waits LP. Assessing allelic dropout and genotype reliability using maximum likelihood. Genetics. 2002;160:357-66.

20. Walsh PS, Erlich HA, Higuchi R. Preferential PCR amplification of alleles: Mechanisms and solutions. Genome Res. 1992;1:241-50.

21. Wilton L, Thornhill A, Traeger-Synodinos J, Sermon KD, Harper JC. The causes of misdiagnosis and adverse outcomes in PGD. Hum Reprod. 2009:24:1221-8.

22. Piriyapongsa J, Piriyapongsa C, Assawamakin A, Wangkumhang P, Suwannasr P, Ruangrit U, Agavatpanitch GG, Tongsima S. RExPrimer: an integrated primer designing tool increases PCR effectiveness by avoiding 3' SNP-in-primer and mis-priming from structural variation. BMC Genomics. 2009;10(Suppl 3):s4.

23. Goossens B, Waits LP, Taberlet P. Plucked hair samples as a source of DNA Reliability of dinucleotide microsatellite genotyping. Mol Ecol. 1998;7:1237-41.

24. Heinrich M, Müller M, Rand S, Brinkmann B, Hohoff C. Allelic drop-out in the STR system ACTBP2 (SE33) as a result of mutations in the primer binding region. Int J Legal Med. 2004;118:361-3.
25. Sint D, Raso L, Traugott M. Advances in multiplex PCR: Balancing primer efficiencies and improving detection success. Methods Ecol Evol. 2012;3:898-905

26. Marshall PL, King JL, Budowle B. Utility of amplification enhancers in low copy number DNA analysis. Int J Legal Med. 2014;129:43-52.

27. Millikan RC, Hummer AJ, Wolff MS, Hishida A, Begg CB. HER2 codon 655 polymorphism and breast cancer: Results from kin-cohort and case-control analyses. Breast Cancer Res Treat. 2005;89:309-12.

28. Siddig A, Mohamed AO, Kamal H, Awad S, Hassan AH, Zilahi E, Al-Haj M, Bernsen R, Adem A. HER-2/neu lle655Val polymorphism and the risk of breast cancer. Ann N Y Acad Sci. 2008;1138:84-94.

29. Naidu R, Yip CH, Taib NA. Polymorphisms of HER2 Ile655Val and cyclin D1 (CCND1) G870A are not associated with breast cancer risk but polymorphic allele of HER2 is associated with nodal metastases. Neoplasma. 2008:55:87-95.

30. An HJ, Kim NK, Oh D, Kim SH, Park MJ, Jung MY, Kang H, Kim SG, Lee KP, Lee KS. Her2 genotype and breast cancer progression in Korean women. Pathol Int. 2005;55:48-52.

31. Hosking L, Lumsden S, Lewis K, Yeo A, McCarthy L, Bansal A, Riley J, Purvis I, $\mathrm{Xu} C$-F. Detection of genotyping errors by Hardy-Weinberg equilibrium testing. Eur J Hum Genet. 2004:12:395-9.

32. Kikin O, Antonio LD, Bagga PS. QGRS Mapper: a web-based server for predicting G-quadruplexes in nucleotide sequences. Nucleic Acids Res. 2006:34:676-82

33. Thornhill AR, McGrath JA, Eady RAJ, Braude PR, Handyside AH. A comparison of different lysis buffers to assess allele dropout from single cells for preimplantation genetic diagnosis. Prenat Diagn. 2001;21:490-7.

34. von Ahsen $E, N$, Oellerich $M$, Schütz. Limitations of Genotyping Based on Amplicon Melting Temperature. Clin Chem. 2001;47(7):2001.

35. Nagy B, Ban Z, Papp Z. The DNA isolation method has effect on allele drop-out and on the results of fluorescent PCR and DNA fragment analysis. Clin Chim Acta. 2005;360:128-32.

36. Gill P, Whitaker J, Flaxman C, Brown N, Buckleton J. An investigation of the rigor of interpretation rules for STRs derived from less than $100 \mathrm{pg}$ of DNA. Forensic Sci Int. 2000;112:17-40.

37. Weiler NEC, Matai AS, Sijen T. Extended PCR conditions to reduce drop-out frequencies in low template STR typing including unequal mixtures. Forensic Sci. Int. Genet. 2012;6:102-7.

38. Weusten J, Herbergs J. A stochastic model of the processes in PCR based amplification of STR DNA in forensic applications. Forensic Sci Int Genet. 2012;6:17-25

39. Bui M, Liu Z. Simple allele-discriminating PCR for cost-effective and rapid genotyping and mapping. Plant Methods. 2009;5:1

40. Rychlik W, Spencer WJ, Rhoads RE. Optimization of the annealing temperature for DNA amplification in vitro. Nucleic Acids Res. 1991;19:698.

41. Pan W, Byrne-steele M, Wang C, Lu S, Clemmons S, Zahorchak RJ. DNA polymerase preference determines PCR priming efficiency DNA polymerase preference determines PCR priming efficiency. BMC Biotechnol. 2014;14(1):1-16.

42. Weissensteiner T, Lanchbury JS. Strategy for controlling preferential amplification and avoiding false negatives in PCR typing. BioTechniques. 1996:21:1102-8.

43. Rees WA, Yager TD, Korte J, von Hippel PH. Betaine can eliminate the base pair composition dependence of DNA melting. Biochemistry. 1993;32:137-44.

44. Henke W, Herdel K, Jung K, Schnorr D, Loening SA. Betaine improves the PCR amplification of GC-rich DNA sequences. Nucleic Acids Res. 1997;25:3957-8.

45. Haqqi P, Zhao X, Panciu A, Yadav S. Sequencing in the presence of betaine: Improvement in sequencing of the localized repeat sequence regions. J Biomol Tech. 2002;13:265-71.

46. Melchior WB Jr, Von Hippel PH. Alteration of the relative stability of dA-dT and dG-dC base pairs in DNA. Proc Natl Acad Sci U S A. 1973;70:298-302.

47. Wei M, Deng J, Feng $K$, Yu B, Chen Y. Universal method facilitating the amplification of extremely GC-Rich DNA fragments from genomic. Anal Chem. 2010:82:6303-7.

48. Soulsbury CD, lossa G, Edwards KJ, Baker PJ, Harris S. Allelic dropout from a high-quality DNA source. Conserv Genet. 2007:8:733-8.

49. Ray PF, Winston RM, Handyside AH. Reduced allele dropout in single-cell analysis for preimplantation genetic diagnosis of cystic fibrosis. J Assist Reprod Genet. 1996;13:104-6.

50. Piyamongkol W, Bermudez MG, Harper JC, Wells D. Detailed investigation of factors influencing amplification efficiency and allele drop-out in single cell 
PCR: implications for preimplantation genetic diagnosis. Mol Hum Reprod. 2003;9:411-20

51. Wenzel JJ, Rossmann H, Fottner C, Neuwirth S, Neukirch C, Lohse P, Bickmann JK, Minnemann T, Musholt TJ, Schneider-ratzke B, Weber MM,

Lackner KJ. Identification and prevention of genotyping errors caused by G-Quadruplex - and i-Motif - like sequences. Clin Chem. 2009;5:1361-71.

Submit your next manuscript to BioMed Central and we will help you at every step:

- We accept pre-submission inquiries

- Our selector tool helps you to find the most relevant journal

- We provide round the clock customer support

- Convenient online submission

- Thorough peer review

- Inclusion in PubMed and all major indexing services

- Maximum visibility for your research

Submit your manuscript at www.biomedcentral.com/submit 